\title{
MESSENGER RNA BASED SKIN IDENTIFICATION USING SKIN SPECIFIC MARKERS FROM FINGERPRINT IMPRESSIONS
}

\author{
Onyekachi Ogbonnaya Iroanya*, Tochukwu Frank Egwuatu, \\ Onyekachi Nneoma Iweha, Ndidiamaka Janet Ezeh, Omowumi Omolade Adeniran
}

University of Lagos, Faculty of Science, Department of Cell Biology and Genetics, Forensic Biology Research Group Laboratory, Akoka, Yaba, Lagos, Nigeria *Corresponding author; Emails: oiroanya@unilag.edu.ng or onyiiog@yahoo.com

(Received April 29, 2020; Accepted May 11, 2020)

\begin{abstract}
The study of forensic science may be complex especially in the areas of nucleic acids and trace evidence. Oftentimes, forensic scientists recover minute quantities of biological material from scenes therefore the need to generate the genetic profiles and identify the source of the material. The aim of this study is to determine the expression levels of skin-specific gene markers - Loricrin ( $L O R)$, Corneodesmosin (CDSN) and Keratine 9 (KRT9), on fingerprint impressions of individuals of specific age group and genders. Thumbprints were collected using labelled frosted microscope glass slides and cello tapes. Messenger RNA was extracted from the samples, converted to cDNA and amplified by qPCR with its specific primer sequences. In males, RNA yield was higher in the slide $(26.96 \pm 8.68)$ compared to cello tape $(18.32 \pm 4.52)$ while the reverse was the case in the females. Across gender, RNA purity and yield were higher in males than females. In males, KRT9, $L O R$ and $C D S N$ genes were more expressed using frosted slide (37.03 \pm 0.77 , $40.46 \pm 2.66,35.62 \pm 2.82$ ) compared to cello tapes $(35.33 \pm 0.3,32.11 \pm 0.5,35.28 \pm 0.86)$ respectively. In females, $L O R, C D S N$ and $A C T B$ genes were more expressed using frosted slides $(36.26 \pm 0.8,37.37 \pm 0.58,26.63 \pm 0.12)$ compared to cello tapes $(35.52 \pm 1.01$, $35.57 \pm 3.22,26.57 \pm 1.18)$ respectively. Across gender, $L O R$, KRT9 and ACTB genes were more expressed in males than females while $C D S N$ was more expressed in females than males. The expression levels of $C D S N$ and $A C T B$ genes were significantly $(\mathrm{p} \leq 0.01)$ correlated. This study shows that mRNA markers $L O R, C D S N$ and $K R T 9$, analysed via the RT-qPCR assays, are highly suitable for identifying skin cells even in small traces.
\end{abstract}

Keywords: skin-specific gene markers, Loricrin, Corneodesmosin, Keratin 9, $\beta$-Actin, cDNA

\section{INTRODUCTION}

There is a strong trend in molecular forensics for the development of alternative techniques to identifying the cellular origin of biological samples and trace evidence collected at crime scenes (HALL et al., 2013). Information about the possible origin of biological samples of forensic traces is mostly ascertained via protein-based presumptive testing and DNA analysis. Messenger RNA-profiling has however emerged as an alternative strategy to 
determine the biological origin of biological materials (ZUBAKOV et al., 2008). Additionally, in order for forensic scientists to overcome the limitations faced currently using for example classical body fluid identification approaches, the use of messenger RNA (mRNA) profiling has been suggested to supplant conventional methods for body fluid identification (JUUSOLA and BALLANTYNE, 2003). This ensures the production of unique gene expression patterns for each cell type which is evidenced by the presence and abundance of specific mRNAs (ALBERTS et al., 1994). Messenger RNA detection is a reliable method for identification of the most common biological samples taken from forensic cases (HAAS, et al., 2009; VISSER et al., 2011; KOHLMEIER and SCHNEIDER 2012). The variation within and between individual skin-specific mRNA as has been observed in some previously described cases, which complicate the determination of the presence of skin using certain markers, has thus pointed to the need for further investigation (HALL et al., 2013).

Skin is an additional forensically relevant cell type and three mRNA transcripts ( $L O R$, $C D S N$ and KRT9) had been reported to show high expression in skin samples relative to other forensically important ant cell types (VISSER et al., 2011). LOR encodes loricrin which is a component of the cornified cell envelope located in terminally differentiated epidermal cells. CDSN encodes corneodesmosin (HAFTEK et al., 2008) and it is involved in desquamation, the process which triggers shedding of the outer membrane layer of the skin (JACKSON et al., 1993). KRT9 is a member of the superfamily of intermediate filament proteins expressed in all different epithelial cell types. KRT9 is expressed only in the suprabasal cells of the epidermis and has previously been reported to be specifically expressed in palmar and plantar skin (SU et al., 2002). The reference gene $A C T B$ (ß-actin), used here for normalising expression signals of skintargeted mRNA markers is a major constituent of the contractile apparatus and one of the two non-muscle cytoskeletal actins. Actins are highly conserved proteins and are involved in ensuring cell motility, structure and integrity (VISSER et al., 2011). LOR, CDSN and KRT9 are the markers used in the study and were selected due to their specificity and sensitivity in skin samplings. A positive control $A C T B$ was used and it has been previously described and used as an endogenous control (LINDENBERGH et al., 2012). The aim of this study was to evaluate the expression levels of skin candidate genes, $L O R, C D S N$ and KRT9 on fingerprint impressions individuals of specific age groups and genders.

\section{MATERIALS AND METHODS}

\section{Sampling}

Thumbprint impressions were collected from twenty healthy individuals (10 males and 10 females) whose ages ranged from 17- 22 years and were grouped into four groups. The left and right thumbprints of 5 males and 5 females were taken on frosted slides while the left and right thumbprints of 5 males and 5 females were taken on cut rectangular transparent cello tape.

The subjects washed their hands with clean water without soap. Thereafter their hands were wiped clean using rubbing alcohol and then allowed to air dry for 30 minutes without contact with anything or anyone. Their left and right thumbprints were then taken with the use of an already labelled and sterilized frosted slides or cut pieces cello tape. The samples were immediately taken to the laboratory for analysis.

\section{Materials used for this study}

The materials used for the study were Pinpoint slide RNA isolation system 1 kit (Zymo Research $^{\circledR}$, LunaScript $^{\circledR}$ RT SuperMix Kit (NEB \#E3010), Luna ${ }^{\circledR}$ Universal qPCR Master Mix Kit (NEB \#M3003), ASI Supreme ${ }^{\text {TM }}$ Frosted Glass Microscope Slides (SM2576) and Scotch ${ }^{\circledR}$ transparent Cello tape. 


\section{Ribonucleic acid (RNA) extraction}

Ribonucleic acid (RNA) was extracted from the samples collected using a Pinpoint slide RNA isolation system 1 kits (Zymo research $®)$ following the manufacturer's instructions. The Pinpoint slide RNA isolation system 1 kit procedure involved two steps which were Pinpoint fractionation to recover fingerprint samples from glass slides and cut cello tapes and RNA extraction for total RNA recovery.

\section{Spectrophotometric analysis}

Ribonucleic Acid (RNA) quality and quantity were determined spectrophotometrically by analysing absorption ratios: A260/230 and A260/280 using a Nanodrop 1000 spectrophotometer (6305 JENWAY spectrometer).

\section{Complementary DNA (cDNA) synthesis}

Complementary DNA (cDNA) synthesis was carried out using the LunaScript RT SuperMix Kit (NEB \#E3010). The cDNA synthesis reaction was prepared by adding $4 \mu 1$ of LunaScript RT SuperMix (1X) to $10 \mu \mathrm{l}$ of the RNA sample and made up to $20 \mu \mathrm{l}$ with $6 \mu \mathrm{l}$ of nuclease-free water. The reactions will then be incubated with primer annealing for 2 minutes at $25{ }^{\circ} \mathrm{C}$, cDNA synthesis for 10 minutes at $55^{\circ} \mathrm{C}$ and heat inactivation for 1 minute at $95{ }^{\circ} \mathrm{C}$.

\section{Real time quantitative polymerase chain reaction (RT-QPCR)}

Real time quantitative PCR (RT-qPCR) was carried using the Luna Universal qPCR Master Mix Kit (NEB \#M3003). Dye-based qPCR detection was prepared using $10 \mu 1$ of Luna Universal qPCR Master Mix (1X), $0.5 \mu 1$ of $10 \mu \mathrm{M}$ forward primer $(0.25 \mu \mathrm{M}), 0.5 \mu 1$ of $10 \mu \mathrm{M}$ reverse primer $(0.25 \mu \mathrm{M}), 2 \mu \mathrm{l}$ of cDNA products and $7 \mu 1$ of Nuclease-free water. Initial denaturation ( 1 cycle) was carried out for 60 seconds at $95^{\circ} \mathrm{C}$, Denaturation (40-45 cycles) for 15 seconds at $95^{\circ} \mathrm{C}$; Extension (40-45 cycles) for 30 seconds at $60{ }^{\circ} \mathrm{C}$; Melt curve $(1$ cycle) at $\left.60-95{ }^{\circ} \mathrm{C}\right)$.

\section{Statistical analysis}

Data generated were analysed using IBM SPSS Version. 26 (IBM SPSS Inc., USA). Analysis of variance (ANOVA) was used to compare group means and mean differences were separated using Duncan Multiple Range Test at $5 \%$ level of significance. Graphs were plotted using GraphPad 8.0.1 software. The comparative Ct method ( $2^{-\Delta \Delta \mathrm{Ct}}$ method) was used to analyse the expression level of the target genes according to LIVAK and SCHMITTGEN (2001) and RAO et al., (2013).

\section{Primers used for the study}

The primer sequences for the target genes and reference gene were designed on Primer blast and validated on Netprimer and Oligo analyzer. The primer sequences are shown in Table 1 .

Table 1: Showing the primer sequences.

\begin{tabular}{ll}
\hline Genes & Primer sequences \\
\hline Beta-Actin $(\boldsymbol{A C T B})$ & Forward Primer - 5'- GACCTGTACGCCAACACAGT - 3' \\
& Reverse Primer - 5' -CTCCTTCTGCATCCTGTCGG - 3', \\
\hline Corneodesmosin $(\boldsymbol{C D S N})$ & Forward Primer - 5' - CTCCTTCTGCATCCTGTCGG - 3' \\
& Reverse Primer - 5' - GGAACCGGATGCACCTTGTA - 3' \\
\hline Keratin9 (KRT9) & Forward Primer - 5'- AGTTGGAGGTGTTTTCCAGGG -3' \\
& Reverse Primer - 5' - TGGGGTTGGGAGGTAGTTGT -3' \\
\hline Loricin (LOR) & Forward Primer - 5'- TGGCTTTCCATTGGCTTCCA -3' \\
& Reverse Primer - 5' - AAGATCGTGCAGGGTGTGAG -3' \\
\hline
\end{tabular}




\section{Ethical clearance}

Informed written consent was obtained from all the study participants, and the study protocol was approved by the Health Research ethics committee of the College of Medicine, University of Lagos (CMULHREC Number: CMUL/HREC/O668/19).

\section{RESULTS}

In Table 2, KRT9, LOR and CDSN genes were more expressed in samples taken on a frosted slide $(37.03 \pm 0.77,40.46 \pm 2.66,35.62 \pm 2.82)$ than cut cello tapes $(35.33 \pm 0.3,32.11$ $\pm 0.5,35.28 \pm 0.86$ ) amongst the male participants respectively. However, the reverse was the case for the $A C T B$ gene which showed that the samples taken on cut cello tapes expressed more of this gene $(27.05 \pm 0.11)$ than the samples collected on frosted slides $(26.94 \pm 0.67)$. Amongst the female participants, $L O R, C D S N$ and $A C T B$ genes were more expressed in samples taken on frosted slides $(36.26 \pm 0.8,37.37 \pm 0.58,26.63 \pm 0.12)$ than those taken on cut cello tapes $(35.52 \pm 1.01,35.57 \pm 3.22,26.57 \pm 1.18)$ respectively. However, the reverse was the case for the KRT9 gene which showed that the samples taken on cut cello tapes expressed more of this gene $(35.4 \pm 2.2)$ than the samples collected on frosted slides $(34.76 \pm 1.24)$. Across gender, $L O R$, KRT9 and ACTB genes were more expressed in males than females while CDSN was more expressed in females than males.

Table 2. Descriptive statistics analysis output of the Cq values generated from RT-qPCR.

\begin{tabular}{|c|c|c|c|c|c|c|}
\hline \multirow[b]{2}{*}{$\begin{array}{l}\text { Candidate } \\
\text { gene (cq) }\end{array}$} & \multirow[b]{2}{*}{ Groups } & \multirow[b]{2}{*}{$\begin{array}{l}\text { Mean } \\
\pm \text { SEM }\end{array}$} & \multicolumn{2}{|c|}{$\begin{array}{c}95 \% \text { Confidence Interval } \\
\text { for Mean }\end{array}$} & \multirow[b]{2}{*}{ Minimum } & \multirow[b]{2}{*}{ Maximum } \\
\hline & & & $\begin{array}{l}\text { Lower } \\
\text { Bound }\end{array}$ & $\begin{array}{l}\text { Upper } \\
\text { Bound }\end{array}$ & & \\
\hline \multirow{4}{*}{ KRT9 } & MS & $37.03 \pm 0.77$ & 34.8811 & 39.1684 & 34.65 & 38.71 \\
\hline & MT & $35.33 \pm 0.3$ & 34.5047 & 36.1639 & 34.29 & 36.04 \\
\hline & FS & $34.76 \pm 1.24$ & 31.3108 & 38.2178 & 30.82 & 38.60 \\
\hline & FT & $35.4 \pm 2.2$ & 29.3026 & 41.5054 & 28.89 & 42.07 \\
\hline \multirow{4}{*}{ LOR } & MS & $40.46 \pm 2.66$ & 33.0742 & 47.8498 & 33.99 & 48.00 \\
\hline & MT & $32.11 \pm 0.5$ & 30.7189 & 33.5091 & 31.02 & 33.92 \\
\hline & FS & $36.26 \pm 0.8$ & 34.0396 & 38.4764 & 34.92 & 38.73 \\
\hline & FT & $35.52 \pm 1.01$ & 32.7301 & 38.3139 & 32.25 & 38.50 \\
\hline \multirow{4}{*}{ CDSN } & MS & $35.62 \pm 2.82$ & 27.7842 & 43.4478 & 28.74 & 45.74 \\
\hline & MT & $35.28 \pm 0.86$ & 32.8871 & 37.6809 & 32.50 & 37.95 \\
\hline & FS & $37.37 \pm 0.58$ & 35.7654 & 38.9666 & 35.62 & 39.01 \\
\hline & FT & $35.57 \pm 3.22$ & 26.6254 & 44.5066 & 26.96 & 44.96 \\
\hline \multirow{4}{*}{$A C T B$} & MS & $26.94 \pm 0.67$ & 25.0915 & 28.7854 & 24.48 & 28.22 \\
\hline & MT & $27.05 \pm 0.11$ & 26.7435 & 27.3640 & 26.76 & 27.34 \\
\hline & FS & $26.63 \pm 0.12$ & 26.2826 & 26.9709 & 26.21 & 26.84 \\
\hline & FT & $26.57 \pm 1.18$ & 23.2819 & 29.8504 & 22.05 & 28.73 \\
\hline
\end{tabular}

MS = Male slide, $\mathrm{FS}=$ Female slide, $\mathrm{MT}=$ Male tape, $\mathrm{FT}=$ Female tape.

At 260/280 absorbance ratio (Table 3), samples which were taken on cut cello tapes yielded purer $(1.96 \pm 0.24)$ RNA than those collected on frosted slides $(2.07 \pm 0.21)$ in male while slide samples yielded purer $(1.73 \pm 0.02)$ RNA than cello tape samples $(1.68 \pm 0.13)$ in females. Also, RNA yield was higher in male slide samples $(26.96 \pm 8.68)$ than cello tape samples $(18.32 \pm 4.52)$ and the reverse was the case in the females. Across gender, RNA purity and yield were higher in males than females. 
Table 3. Descriptive statistics analysis output of RNA spectrophotometric values.

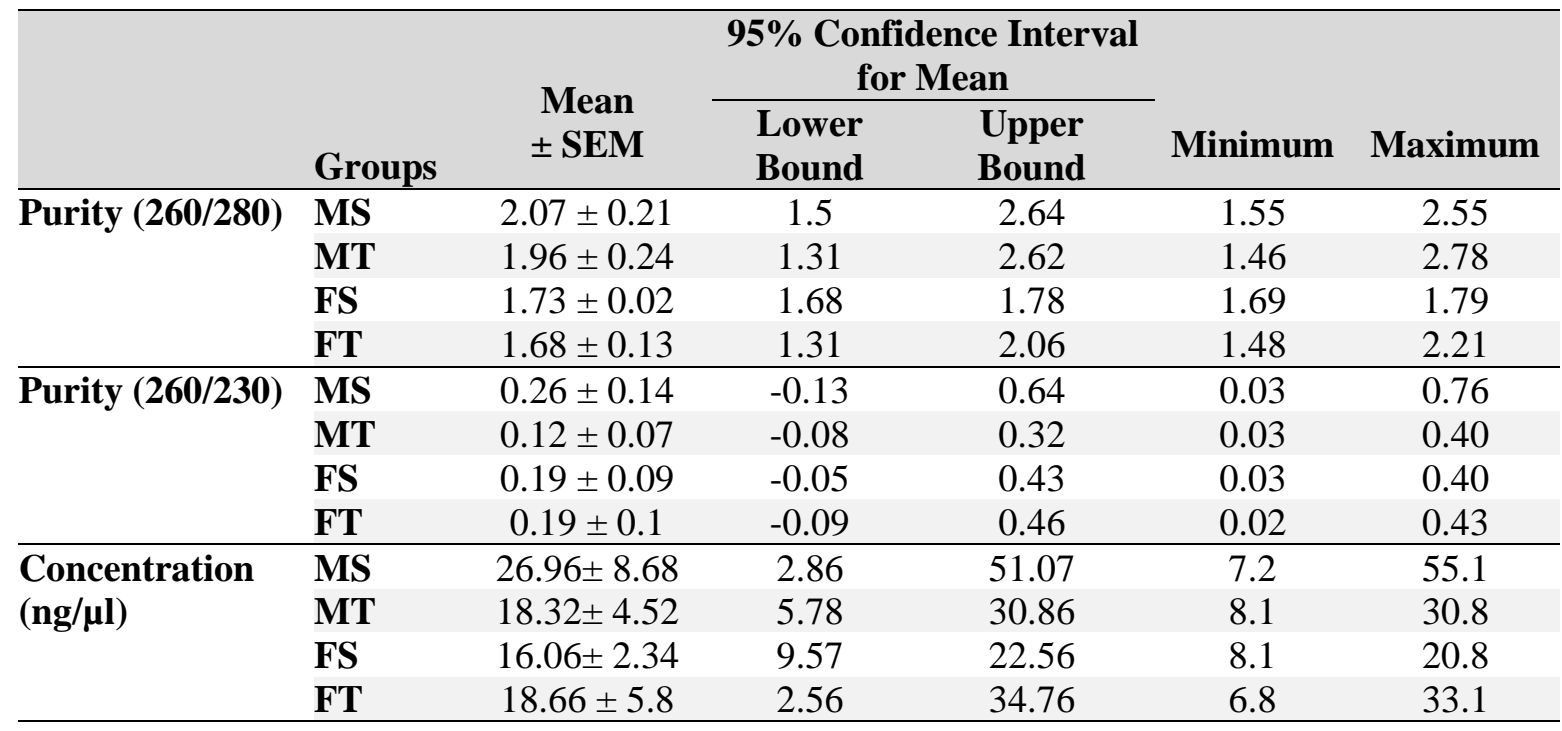

MS = Male slide, $\mathrm{FS}=$ Female slide, $\mathrm{MT}=$ Male tape, $\mathrm{FT}=$ Female tape.

Table 4 shows that there was no significant difference in Cq values of KRT 9, CDSN and the $A C T B$ gene across gender and type of surfaces used. There was a significant difference ( $\mathrm{p} \leq 0.05$ ) between the expression of the LOR gene in samples collected on slides and cello tapes among the males. Also, there was a significant difference $(\mathrm{p} \leq 0.05)$ between the expression of the $L O R$ gene in female samples collected cello tapes and male samples taken on slides.

Table 5 shows that there was no significant difference in spectrophotometric values of all extracted RNA samples at 260/280 and 260/230 absorbance ratio and in the concentration values across gender and type of surfaces used.

In Table 6, Pearson correlation analysis showed that there was a correlation between the expression levels of $C D S N$ and $A C T B$ genes at 0.01 level of significance. However, the $A C T B$ expression level did not correlate with the expression levels of $K R T 9$ and $L O R$ genes ( $>00.05)$. Also, RNA Purity (260/230) correlated with concentration at 0.01 level of significance.

In Table 7, Spearman's rho correlation analysis showed that there was a correlation between the expression levels of $C D S N$ and $A C T B$ genes at 0.05 level of significance. Also, RNA Purity (260/230) correlated with concentration at 0.01 level of significance.

In Table 8, Kendall's tau-b correlation analysis showed that there was a correlation between the expression levels of $C D S N$ and $A C T B$ genes at 0.05 level of significance. Also, RNA Purity (260/230) correlated with concentration at 0.01 level of significance.

\section{DISCUSSION}

Forensic biologists have used fingerprint impressions to generate DNA profiles over the years (VAN OORSCHOT and JONES, 1997; TEMPLETON and LINACRE, 2014; SINELNIKOV and REICH, 2017; SUBHANI, et al., 2018; ROMANO et al., 2019) yet, there is not a definitive test to determine the presence of skin epithelial cells in trace biological materials. Obtaining DNA profiles from trace biological evidence is routinely demonstrated with forensic 'touch DNA evidence samples. Oftentimes, genetic profiles obtained cannot be linked to the tissue source of the profiles and thus is usually rarely known (BUDOWLE et al., 2009; GILBERT, 2010). 
Table 4: Multiple comparison showing Post-hoc tests of skin mRNA marker across gender and type of surfaces used.

\begin{tabular}{|c|c|c|c|c|c|}
\hline \multirow{2}{*}{ Gene (cq) } & \multicolumn{2}{|c|}{ Sample } & \multicolumn{3}{|c|}{ Significance $(p \leq 0.05)$} \\
\hline & Group & Groups & Tukey HSD & Tukey LSD & Dunnett T3 \\
\hline \multirow{12}{*}{ KRT9 } & \multirow{3}{*}{ MS } & MT & 0.81 & 0.38 & 0.36 \\
\hline & & FS & 0.63 & 0.25 & 0.58 \\
\hline & & FT & 0.82 & 0.40 & 0.97 \\
\hline & \multirow{3}{*}{ MT } & MS & 0.81 & 0.38 & 0.36 \\
\hline & & FS & 0.99 & 0.77 & 1.00 \\
\hline & & FT & 1.00 & 0.97 & 1.00 \\
\hline & \multirow{3}{*}{ FS } & MS & 0.63 & 0.25 & 0.58 \\
\hline & & MT & 0.99 & 0.77 & 1.00 \\
\hline & & FT & 0.99 & 0.74 & 1.00 \\
\hline & \multirow{3}{*}{ FT } & MS & 0.82 & 0.40 & 0.97 \\
\hline & & MT & 1.00 & 0.97 & 1.00 \\
\hline & & FS & 0.99 & 0.74 & 1.00 \\
\hline \multirow{12}{*}{ LOR } & \multirow{3}{*}{ MS } & MT & $0.01^{*}$ & $0.001^{*}$ & 0.14 \\
\hline & & FS & 0.24 & 0.07 & 0.61 \\
\hline & & FT & 0.13 & $0.03^{*}$ & 0.49 \\
\hline & \multirow{3}{*}{ MT } & MS & $0.01^{*}$ & $0.001^{*}$ & 0.14 \\
\hline & & FS & 0.25 & 0.07 & 0.02 \\
\hline & & FT & 0.40 & 0.13 & 0.11 \\
\hline & \multirow{3}{*}{ FS } & MS & 0.24 & 0.07 & 0.61 \\
\hline & & MT & 0.25 & 0.07 & 0.02 \\
\hline & & FT & 0.99 & 0.73 & 0.99 \\
\hline & \multirow{3}{*}{ FT } & MS & 0.13 & $0.03^{*}$ & 0.49 \\
\hline & & MT & 0.40 & 0.13 & 0.11 \\
\hline & & FS & 0.99 & 0.73 & 0.99 \\
\hline \multirow{12}{*}{ CDSN } & \multirow{3}{*}{ MS } & MT & 1.00 & 0.92 & 1.00 \\
\hline & & FS & 0.94 & 0.58 & 0.98 \\
\hline & & FT & 1.00 & 0.99 & 1.00 \\
\hline & \multirow{3}{*}{ MT } & MS & 1.00 & 0.92 & 1.00 \\
\hline & & FS & 0.91 & 0.52 & 0.35 \\
\hline & & FT & 1.00 & 0.93 & 1.00 \\
\hline & \multirow{3}{*}{ FS } & MS & 0.94 & 0.58 & 0.98 \\
\hline & & MT & 0.91 & 0.52 & 0.35 \\
\hline & & FT & 0.94 & 0.57 & 0.98 \\
\hline & \multirow{3}{*}{ FT } & MS & 1.00 & 0.99 & 1.00 \\
\hline & & MT & 1.00 & 0.93 & 1.00 \\
\hline & & FS & 0.94 & 0.57 & 0.98 \\
\hline \multirow{12}{*}{$A C T B$} & \multirow{3}{*}{ MS } & MT & 1.00 & 0.91 & 1.00 \\
\hline & & FS & 0.99 & 0.75 & 1.00 \\
\hline & & FT & 0.98 & 0.71 & 1.00 \\
\hline & \multirow{3}{*}{ MT } & MS & 1.00 & 0.91 & 1.00 \\
\hline & & FS & 0.97 & 0.67 & 0.16 \\
\hline & & FT & 0.96 & 0.62 & 1.00 \\
\hline & & MS & 0.98 & 0.75 & 1.00 \\
\hline & FS & MT & 0.97 & 0.67 & 0.16 \\
\hline & & FT & 1.00 & 0.95 & 1.00 \\
\hline & & MS & 0.98 & 0.71 & 1.00 \\
\hline & FT & MT & 0.96 & 0.62 & 1.00 \\
\hline & & FS & 1.00 & 0.95 & 1.00 \\
\hline
\end{tabular}


Table 5: Multiple comparison showing Post-hoc tests of spectrophotometric values of all extracted RNA samples at 260/280 and 260/230 absorbance ratio and the concentration values across gender and type of surfaces used.

\begin{tabular}{|c|c|c|c|c|c|}
\hline \multirow[b]{2}{*}{ Parameter } & \multirow{2}{*}{$\begin{array}{l}\text { Sample } \\
\text { Group }\end{array}$} & \multirow[b]{2}{*}{ Groups } & \multicolumn{3}{|c|}{ Post Hoc test } \\
\hline & & & Tukey HSD & Tukey LSD & Dunnett T3 \\
\hline \multirow{12}{*}{$\begin{array}{l}\text { Purity } \\
(260 / 280)\end{array}$} & \multirow{3}{*}{ MS } & MT & 0.97 & 0.67 & 1.00 \\
\hline & & FS & 0.51 & 0.18 & 0.55 \\
\hline & & FT & 0.41 & 0.13 & 0.57 \\
\hline & \multirow{3}{*}{ MT } & MS & 0.97 & 0.67 & 1.00 \\
\hline & & FS & 0.76 & 0.34 & 0.87 \\
\hline & & FT & 0.66 & 0.26 & 0.87 \\
\hline & \multirow{3}{*}{ FS } & MS & 0.51 & 0.18 & 0.55 \\
\hline & & MT & 0.76 & 0.34 & 0.87 \\
\hline & & FT & 1.00 & 0.86 & 1.00 \\
\hline & \multirow{3}{*}{ FT } & MS & 0.41 & 0.13 & 0.57 \\
\hline & & MT & 0.66 & 0.26 & 0.87 \\
\hline & & FS & 1.00 & 0.86 & 1.00 \\
\hline \multirow{12}{*}{$\begin{array}{l}\text { Purity } \\
(260 / 230)\end{array}$} & \multirow{3}{*}{ MS } & MT & 0.78 & 0.36 & 0.93 \\
\hline & & FS & 0.97 & 0.65 & 1.00 \\
\hline & & FT & 0.96 & 0.63 & 1.00 \\
\hline & \multirow{3}{*}{ MT } & MS & 0.78 & 0.36 & 0.93 \\
\hline & & FS & 0.96 & 0.63 & 0.98 \\
\hline & & FT & 0.97 & 0.65 & 0.99 \\
\hline & \multirow{3}{*}{ FS } & MS & 0.97 & 0.65 & 1.00 \\
\hline & & MT & 0.96 & 0.63 & 0.98 \\
\hline & & FT & 1.00 & 0.99 & 1.00 \\
\hline & \multirow{3}{*}{ FT } & MS & 0.96 & 0.63 & 1.00 \\
\hline & & MT & 0.97 & 0.65 & 0.99 \\
\hline & & FS & 1.00 & 0.99 & 1.00 \\
\hline \multirow{12}{*}{$\begin{array}{l}\text { Conc. } \\
(\mathrm{ng} / \mu \mathrm{l})\end{array}$} & \multirow{3}{*}{ MS } & MT & 0.72 & 0.31 & 0.92 \\
\hline & & FS & 0.56 & 0.20 & 0.77 \\
\hline & & FT & 0.75 & 0.33 & 0.95 \\
\hline & \multirow{3}{*}{ MT } & MS & 0.72 & 0.31 & 0.92 \\
\hline & & FS & 0.99 & 0.79 & 1.00 \\
\hline & & FT & 1.00 & 0.97 & 1.00 \\
\hline & \multirow{3}{*}{ FS } & MS & 0.56 & 0.20 & 0.77 \\
\hline & & MT & 0.99 & 0.79 & 1.00 \\
\hline & & FT & 0.99 & 0.76 & 1.00 \\
\hline & \multirow{3}{*}{ FT } & MS & 0.75 & 0.33 & 0.95 \\
\hline & & MT & 1.00 & 0.97 & 1.00 \\
\hline & & FS & 0.99 & 0.76 & 1.00 \\
\hline
\end{tabular}

MS = Male slide, $\mathrm{FS}=$ Female slide, $\mathrm{MT}=$ Male tape, $\mathrm{FT}=$ Female tape 
Table 6: Pearson correlation analysis between the expression levels of the genes, RNA purity and concentration.

\begin{tabular}{|c|c|c|c|c|c|c|c|}
\hline \multirow{2}{*}{ Parameter } & \multicolumn{4}{|c|}{ Genes (cq) } & \multicolumn{2}{|c|}{ Purity } & \multirow{2}{*}{$\begin{array}{l}\text { Conc. } \\
(\mu \mathrm{g} / \mu \mathrm{l})\end{array}$} \\
\hline & KRT9 & $L O R$ & CDSN & $A C T B$ & $(260 / 280)$ & $(260 / 230)$ & \\
\hline \multirow[t]{2}{*}{ KRT9 (cq) } & 1 & -0.003 & -0.13 & -0.25 & 0.25 & 0.17 & 0.19 \\
\hline & & 0.99 & 0.60 & 0.29 & 0.29 & 0.49 & 0.43 \\
\hline \multirow[t]{2}{*}{ LOR (cq) } & -0.003 & 1 & 0.26 & 0.13 & 0.10 & 0.001 & 0.09 \\
\hline & 0.99 & & 0.28 & 0.59 & 0.69 & 1.00 & 0.72 \\
\hline \multirow{2}{*}{$\overline{C D S N}(\mathrm{cq})$} & -0.13 & 0.26 & 1 & $0.69^{* * *}$ & -0.33 & -0.20 & -0.24 \\
\hline & 0.60 & 0.28 & & 0.001 & 0.16 & 0.41 & 0.31 \\
\hline \multirow[t]{2}{*}{$\overline{A C T B}(\mathrm{cq})$} & -0.25 & 0.13 & $0.69^{* *}$ & 1 & -0.29 & -0.11 & -0.03 \\
\hline & 0.29 & 0.59 & 0.001 & & 0.21 & 0.66 & 0.89 \\
\hline \multirow{2}{*}{$\begin{array}{l}\text { Purity } \\
(260 / 280)\end{array}$} & 0.25 & 0.10 & -0.33 & -0.29 & 1 & -0.06 & -0.09 \\
\hline & 0.29 & 0.69 & 0.16 & 0.21 & & 0.81 & 0.72 \\
\hline \multirow{2}{*}{$\begin{array}{l}\text { Purity } \\
(260 / 230)\end{array}$} & 0.17 & 0.001 & -0.20 & -0.11 & -0.06 & 1 & $0.82^{* * *}$ \\
\hline & 0.49 & 1.00 & 0.41 & 0.66 & 0.81 & & 0.00 \\
\hline \multirow{2}{*}{$\begin{array}{l}\text { Conc. } \\
(\mu \mathrm{g} / \mu \mathrm{l})\end{array}$} & 0.19 & 0.09 & -0.24 & -0.03 & -0.09 & $0.82^{* *}$ & 1 \\
\hline & 0.43 & 0.72 & 0.31 & 0.89 & 0.72 & 0.00 & \\
\hline
\end{tabular}

$* *=$ Correlation is significant at the 0.01 level.

Table 7: Nonparametric Correlations (Spearman's rho correlation) analysis between the expression levels of the genes, RNA purity (260/280 and 260/230) and concentration.

\begin{tabular}{|c|c|c|c|c|c|c|c|}
\hline \multirow{2}{*}{ Parameter } & \multicolumn{4}{|c|}{ Genes (cq) } & \multicolumn{2}{|c|}{ Purity } & \multirow{2}{*}{$\begin{array}{l}\text { Conc. } \\
(\mu \mathrm{g} / \mu \mathrm{I})\end{array}$} \\
\hline & KRT9 & LOR & CDSN & $A C T B$ & $(260 / 280)$ & $(260 / 230)$ & \\
\hline \multirow[t]{2}{*}{ KRT9 (cq) } & 1.00 & -0.04 & -0.29 & -0.12 & 0.21 & 0.21 & 0.18 \\
\hline & & 0.89 & 0.22 & 0.62 & 0.37 & 0.38 & 0.46 \\
\hline \multirow[t]{2}{*}{$\overline{L O R}$ (cq) } & -0.04 & 1.00 & 0.13 & 0.09 & 0.17 & 0.01 & 0.12 \\
\hline & 0.89 & & 0.60 & 0.72 & 0.47 & 0.97 & 0.62 \\
\hline \multirow[t]{2}{*}{$\overline{C D S N}$ (cq) } & -0.29 & 0.13 & 1.00 & $0.49^{*}$ & -0.22 & -0.05 & -0.15 \\
\hline & 0.22 & 0.60 & & 0.03 & 0.36 & 0.83 & 0.52 \\
\hline \multirow[t]{2}{*}{$\overline{A C T B}$ (cq) } & -0.12 & 0.09 & $0.49^{*}$ & 1.00 & -0.27 & 0.01 & 0.11 \\
\hline & 0.62 & 0.72 & 0.03 & & 0.25 & 0.96 & 0.64 \\
\hline \multirow{2}{*}{$\begin{array}{l}\text { Purity } \\
(260 / 280)\end{array}$} & 0.21 & 0.17 & -0.22 & -0.27 & 1.00 & -0.38 & -0.36 \\
\hline & 0.37 & 0.47 & 0.36 & 0.25 & & 0.10 & 0.12 \\
\hline \multirow{2}{*}{$\begin{array}{l}\text { Purity } \\
(260 / 230)\end{array}$} & 0.21 & 0.01 & -0.05 & 0.01 & -0.38 & 1.00 & $0.88^{* * *}$ \\
\hline & 0.38 & 0.97 & 0.83 & 0.96 & 0.10 & & 0.00 \\
\hline \multirow{2}{*}{$\begin{array}{l}\text { Conc. } \\
(\mu \mathrm{g} / \mu \mathrm{l})\end{array}$} & 0.18 & 0.12 & -0.15 & 0.11 & -0.36 & $0.88^{* * *}$ & 1.00 \\
\hline & 0.46 & 0.62 & 0.52 & 0.64 & 0.12 & 0.00 & \\
\hline
\end{tabular}

* = Correlation is significant at the 0.05 level.

** =Correlation is significant at the 0.01 level. 
Table 8: Nonparametric Correlations (Kendall's tau-b correlation) analysis between the expression levels of the genes, RNA purity (260/280 and 260/230) and concentration.

\begin{tabular}{|c|c|c|c|c|c|c|c|}
\hline \multirow[b]{2}{*}{ Parameter } & \multicolumn{4}{|c|}{ Genes (cq) } & \multicolumn{2}{|c|}{ Purity } & \multirow{2}{*}{$\begin{array}{l}\text { Conc. } \\
(\mu \mathrm{g} / \mu \mathrm{l})\end{array}$} \\
\hline & KRT9 & LOR & CDSN & $A C T B$ & $(260 / 280)$ & $(260 / 230)$ & \\
\hline \multirow[t]{2}{*}{ KRT9 (cq) } & 1.00 & -0.01 & -0.21 & -0.06 & 0.16 & 0.18 & 0.10 \\
\hline & & 0.95 & 0.19 & 0.70 & 0.33 & 0.29 & 0.54 \\
\hline \multirow[t]{2}{*}{$\overline{L O R}(\mathrm{cq})$} & -0.01 & 1.00 & 0.13 & 0.04 & 0.13 & 0.02 & 0.05 \\
\hline & 0.95 & & 0.44 & 0.80 & 0.44 & 0.90 & 0.77 \\
\hline \multirow[t]{2}{*}{$\overline{C D S N}(\mathrm{cq})$} & -0.21 & 0.13 & 1.00 & $0.39^{*}$ & -0.13 & -0.02 & -0.12 \\
\hline & 0.19 & 0.44 & & 0.02 & 0.44 & 0.90 & 0.46 \\
\hline \multirow[t]{2}{*}{$\overline{A C T B}$ (cq) } & -0.06 & 0.04 & $0.39^{*}$ & 1.00 & -0.21 & 0.01 & 0.10 \\
\hline & 0.70 & 0.80 & 0.02 & & 0.19 & 0.95 & 0.54 \\
\hline \multirow{2}{*}{$\begin{array}{l}\text { Purity } \\
(260 / 280)\end{array}$} & 0.16 & 0.13 & -0.13 & -0.21 & 1.00 & -0.29 & -0.24 \\
\hline & 0.33 & 0.44 & 0.44 & 0.19 & & 0.09 & 0.14 \\
\hline \multirow{2}{*}{$\begin{array}{l}\text { Purity } \\
(260 / 230)\end{array}$} & 0.18 & 0.02 & -0.02 & 0.01 & -0.29 & 1.00 & $0.77^{* * *}$ \\
\hline & 0.29 & 0.90 & 0.90 & 0.95 & 0.09 & & 0.00 \\
\hline \multirow{2}{*}{$\begin{array}{l}\text { Conc. } \\
(\mu \mathrm{g} / \mu \mathrm{l})\end{array}$} & 0.10 & 0.05 & -0.12 & 0.10 & -0.24 & $0.77^{* * *}$ & 1.00 \\
\hline & 0.54 & 0.77 & 0.46 & 0.54 & 0.14 & 0.00 & \\
\hline
\end{tabular}

* = Correlation is significant at the 0.05 level.

$* *=$ Correlation is significant at the 0.01 level.

The inability to link the DNA profiles to the tissue source and prove that the DNA originated specifically from skin cells can lead to challenges against DNA evidence in court. Proper identification of the biological materials present forensic samples is important to the investigation, personalization and prosecution of a criminal offense and a misrepresentation of the nature of the evidence can have undue influence on the perception of the circumstance of the crime. Currently, there are no routinely validated methodologies used for the identification of skin epithelial cells. Utilization of mRNA profiling for the identification of forensically relevant biological fluids such as blood, semen, saliva, vaginal secretions and menstrual blood has been documented (JUUSOLA, and BALLANTYNE, 2003, 2005; HAAS et al., 2009). Hence, the need for the development and validation of an mRNA assay that targets highly overexpressed genes in skin in relation to other cell types usually encountered in crime scenes is crucial.

From the study, RNA yield ranged from 7.2 - $55.1 \mathrm{ng} / \mu \mathrm{l}$ in males and $6.8-33.1 \mathrm{ng} / \mu \mathrm{l}$ in females. Also, the RNA yield was higher in males than females. This agrees with the report of HANSON et al., (2011), who reported that the total input RNA should range from (5 - 25 pg) to be exquisitely sensitive to detect skin traces in evidentiary items.

$K R T 9, A C T B$ and $L O R$ markers were more expressed in males than females while CDSN was more expressed in females than males. Across gender, KRT9, CDSN and LOR markers were more expressed than ACTB. These three target genes KRT9, CDSN and LOR were moderately expressed in the fingerprint impressions taken on frosted slides and cut cello tapes. Hence, this makes them suitable markers for skin cell identification and this agrees with the report of VISSER et al., (2011), documented that CDSN, LOR and KRT9 genes showed strong over-expression in skin samples relative to samples from forensic body fluids and thus make them suitable markers for skin identification. However, HALL et al., (2013), reported that they failed to detect KRT9 in any of the donors' soles (or arms) and only one participant indicated the presence of this marker in their palm. Hence, they suggested that these markers must be used with caution in the identification of skin cells in forensic samples. Additionally, GoMES et al., (2011) documented that they encountered detection problems for the KRT9 gene which they linked to non-stringency of the pair of primers used and because preliminary results suggest a probable lower sensitivity of detection for KRT9 in the analysed skin tissues. LOR 
had the highest expression level $(40.46 \pm 2.66)$ and this agrees with the findings of HALL et al., (2013), who reported that $L O R$ was also detected most frequently in the face and palm, as well as the leg; $61 \%, 57 \%$ and $64 \%$ respectively. GoMES et al., (2011), also reported that LOR was a more stable and sensitive mRNA marker for human skin identification thus, CDSN and KRT9 should not be used alone, but concomitant with $L O R$.

The difference between the expression levels of the $L O R$ gene in male and cut cello tape samples was significant $(\mathrm{p} \leq 0.05)$. Also, a significant difference was observed between the female tape and male slide samples $(\mathrm{p} \leq 0.05)$. CDSN expression level correlated with the expression of $A C T B(\mathrm{p} \leq 0.01)$ but did not correlate with LOR and KRT9. HALL et al., (2013), documented that $C D S N$ was observed to be the most sensitive marker, with the greatest expression rates detected in swabs taken from the forehead.

\section{CONCLUSION}

Messenger RNA (mRNA) profiling has been reported to be a good method used to identify most forensic materials obtained from forensic scenes. The mRNA markers $L O R$, $C D S N$ and KRT9, analysed via the described qPCR assays, are highly suitable for identifying skin cells, including small traces of skin materials. Although the approach for skin identification introduced here can be improved upon to be more informative when applied on its own, however, it is recommended that the inclusion of other skin-targeted mRNA markers in multiplex systems, targeting other forensically relevant cell types should be used for further studies.

\section{References:}

[1] Alberts, B., Bray, D., Lewis, J., RAFF, M., Roberts, K., WAtson, J.D. (1994): Molecular Biology of the Cell. Garland Publishing.

[2] Budowle, B. Eisenberg, A.J., Van DaAl, A. (2009): Validity of low copy number typing and applications to forensic science. Croatian Medical Journal 50 (3): 207-217. doi: $10.3325 / \mathrm{cmj} .2009 .50 .207$

[3] GILBERT, N. (2010): Science in court: DNA's identity crisis. Nature 464 :347-348.

[4] Gomes, I., Kohler, F., Schneider, P.M. (2011): Genetic markers for body fluid and tissue identification in forensics. Forensic and Science International 3 (1): e469-e470. doi: org/10.1016/j.fsigss.2011.09.096

[5] HaAs, C., Klesser, B., MaAke, C., BÄr, W., Kratzer, A. (2009): mRNA profiling for body fluid identification by reverse transcription endpoint PCR and realtime PCR. Forensic Science International: Genetics 3 (2): 80-88.

doi: 10.1016/j.fsigen.2008.11.003

[6] Haftek, M., Simon, M., Kanitakis, J., Marechal, S., Claudy, A., Serre, G., Schmitt, D. (2008): Expression of $C D S N$ in the granular layer and stratum corneum of normal and diseased epidermis, British Journal of Dermatology 137 (6): 864-873. doi: 10.1046/j.1365-2133.1997.19792087.x

[7] Hall, S.E., Van OoRschot, R.A.H., Mitchell, R.J., Ballantyne, K.N. (2013): A validation study of mRNA markers for skin cell identification. Forensic Science International: Genetics Supplement Serie. 4 (1): e129- e130. 
doi: 10.1016/j.fsigss.2013.10.066

[8] Hanson, E., HaAs, C., Jucker, R., Ballantyne J. (2011): Identification of skin in touch/contact forensic samples by messenger RNA profiling. Forensic Science International: Genetics Supplement Series 3 (1): e305-e306.

doi: 10.1016/j.fsigss.2011.09.015

[9] Jackson, S.M., Williams, M.L., Feingold, K.R., Elias, P.M. (1993): Pathobiology of the stratum corneum, The Western Journal of Medicine. 158 (3): 279-285. PMCID: PMC1311754

[10] JuUsOla, J., BALlANTYNE, J. (2003): Messenger RNA profiling: a prototype method to supplant conventional methods for body fluid identification, Forensic Science International 135 (2) :85-96. doi: 10.1016/S0379-0738(03)00197-X

[11] JuUsola, J., BALlantYNe, J. (2005): Multiplex mRNA profiling for the identification of body fluids, Forensic Science International. 152 (1): 1-12.

doi: 10.1016/j.forsciint.2005.02.020

[12] KoHLmeier, F., Schneider, P.M. (2012): Successful mRNA profiling of 23 years old bloodstains, Forensic Science International. 6 (2): 274-276.

doi: 10.1016/j.fsigen.2011.04.007.

[13] Lindenbergh, A., De Pagter, M., Ramdayal, G., Visser, M., Zubakov, D., Kayser, M., SIJEN, T. (2012): A multiplex (m)RNA-profiling system for the forensic identification of body fluids and contact traces. Forensic Science International: Genetics. 6 (5): 565 577. doi: 10.1016/j.fsigen.2012.01.009

[14] LiVAK, K.J., SchmitTGEN, T.D. (2001): Analysis of relative gene expression data using real-time quantitative PCR and the 2(-Delta Delta C(T)) method. Methods 25: 402-408. doi: 10.1006/meth.2001.1262.

[15] RaO, X., Huang, X., Zhou, Z., Lin, X. (2013): An improvement of the $2^{\wedge}$ (-delta delta CT) method for quantitative real-time polymerase chain reaction data analysis. The Biostatistics, Bioinformatics and Biomathematics. 3 (3): 71-85. PMCID: PMC4280562

[16] Romano, C.G., Mangiaracina, R., Donato, L., D’angelo, R., Scimone, C., Sidoti, A. (2019): Aged fingerprints for DNA profile: First report of successful typing. Forensic Science International. 302:109905. doi: 10.1016/j.forsciint.2019.109905

[17] Sinelnikov, A., ReICH, K.A. (2017): Materials and methods that allow fingerprint analysis and DNA profiling from the same latent evidence. Forensic Science International Genetics Supplement Series. 6: e40 - e42. doi: 10.1016/j.fsigss.2017.09.010

[18] Su, A.I., CoOKe. M.P., Ching, K.A., Hakak, Y., Walker, J.R., Wiltshire, T., Orth, A.P., Vega, R.G., SAPinoso, L.M., MoQRich, A., PAtapoutian, A., Hampton, G.M., Schultz, P.G., Hogenesch, J.B. (2002): Large-scale analysis of the human and mouse transcriptomes. Proceedings of the National Academy of Sciences. 99 (7): 4465-4470. doi: 10.1073/pnas.012025199

[19] Subhani, Z., Daniel, B., Frascione, N. (2018): DNA Profiles from Fingerprint LiftsEnhancing the Evidential Value of Fingermarks Through Successful DNA Typing. Journal of Forensic Sciences. 64 (1): 201 -206. doi: 10.1111/1556-4029.13830

[20] TEMPleton, J.E., LinACRE, A. (2014): DNA profiles from fingermarks. Biotechniques. 57 (5): 259-66. doi: 10.2144/000114227 
[21] VAN OORSCHOT, R.A., JONES, M.K. (1997): DNA fingerprints from fingerprints. Nature 387 (6635): 767.

[22] VisSer, M., ZubaKov, D., BALlANTYNe, K.N., KAYSER, M. (2011): mRNA-based skin identification for forensic application. International Journal of Legal Medical 125 (2): 253-263. doi: 10.1007/s00414-010-0545-2

[23] Zubakov, D., Hanekamp, E., KoKshoorn, M., VAn IjcKen, W., Kayser, M. (2008): Stable RNA markers for identification of blood and saliva stains revealed from whole genome expression analysis of time-wise degraded samples. International Journal of Legal Medicine 122 (2): 135-142. doi: 10.1007/s00414-007-0182-6 